\title{
ECONOMICS OF DEFENSE PROCUREMENT AND SMALL BUSINESS
}

\author{
David Novick* and J. Y. Springer†
}

Since the end of World War II and particularly since the Korean incident, military procurement has achieved a peace-time volume never before contemplated in our history. This high level of activity and the likelihood that it will continue for a long time give defense spending a new importance in the national economy, and especially in selected industries-such as electronics, airframes, ships, or jet and rocket power plants. Under these conditions, it is logical that small business should seek participation in this new and large opportunity, since it always has been in competition to serve other kinds of economic demands.

This paper examines the magnitude and nature of military procurement and the special commercial considerations involved. The analysis concentrates on specialized military equipment and gives only passing attention to the problems of doing business with the military in such commodities as shoes, clothing, typewriters, meat and vegetable products, and a multitude of other items the services buy that are similar to or identical with standard articles of commerce.

The main concern of this study, therefore, is centered on the economics of procurement of weapons and the related and specialized equipment essential to their operation. It will of necessity include components, materials, special products, and services required for weapons and their directly related equipment.

This leads to consideration of the weapon-system concept of procurement management which has grown up in the last four years. Although the emphasis is on the economics of weapons, it is essential to take into account the national security considerations which compel a distinction between the market for these goods and that which prevails in normal commercial contracts.

Special contract and legal considerations are not included here. Instead, this paper deals only with the economic and national security considerations and does not treat with either the legal or moral issues involved.

\section{I}

\section{Magnitude of Defrense Procurement Since 1940}

The national annual volume of business has expanded fourfold since 1940; during this same period, national security expenditures have expanded at a much more rapid

* Ph.B. 1929, Brown University; A.M. r930, Lafayette College. Chief, Cost Analysis Department, The Rand Corporation; Member, Mobilization Advisory Committee. Formerly Controller, War Production Board; Consultant, SRB, ODM, NPA. Author, Wartime Production Controls (1949), Wartime InDUSTRAal Reporting (I950), and various works on the economic problems of national security.

† A.B. I927, M.B.A. 1929, Ph.D. 1942, Stanford University. Cost Analysis Department, The RaND Corporation. Formerly Assistant Director of Research, Hawaii Employers Council. 
rate. ${ }^{1}$ From a level of $\$ 100,000,000,000$ in 1940 , the gross national product has grown to $\$ 434,000,000,000$ in 1957 , a growth of over 300 per cent. During this same period, national security expenditures which amounted to only $\$ 2,000,000,000$ in I940 had grown to $\$ 46,000,000,000$ in 1957 or more than twenty times the r940 level. The annual changes in gross national product and in national security expenditures over this eighteen-year period are shown in table one and portrayed in chart one below.

TABLE I

Gross Nattonal Product and National Security Expenditures, I940-57 (billions of dollars)

\begin{tabular}{l|c|c|c|c|c}
\hline Year & $\begin{array}{c}\text { Gross National } \\
\text { Product }\end{array}$ & $\begin{array}{c}\text { National Security } \\
\text { Expenditures }\end{array}$ & Year & $\begin{array}{c}\text { Gross National } \\
\text { Product }\end{array}$ & $\begin{array}{c}\text { National Security } \\
\text { Expenditures }\end{array}$ \\
\cline { 2 - 3 } 1940 & $\$ 100.6$ & $\$ 2.2$ & 1950 & $\$ 285.1$ & $\$ 18.5$ \\
1941 & 125.8 & 13.8 & 1951 & 328.2 & 37.3 \\
1942 & 159.1 & 49.6 & 1952 & 345.4 & 48.8 \\
1943 & 192.5 & 80.4 & 1953 & 363.2 & 51.5 \\
1944 & 211.4 & 88.6 & 1954 & 361.2 & 43.1 \\
1945 & 213.6 & 75.9 & 1955 & 391.7 & 41.3 \\
1946 & 209.2 & 21.2 & 1956 & 414.7 & 42.4 \\
1947 & 232.2 & 13.3 & 1957 & 434.4 & 45.7 \\
1948 & 257.3 & 16.0 & & & \\
1949 & 257.3 & 19.3 & & & \\
\hline
\end{tabular}

source: J. S. Dep't. of Commerce, Surrey of Current Business, July 1957, p. 9, and Feb. 1958, p. 8.

National security expenditures today represent a greater economic force than any other single major activity. The volume approximates the combined sales of the nine largest United States industrial corporations. It is greater than that of the automobile industry or the railroads. Only residential housing and public construction even approach in economic significance the military total. As a consequence of this magnitude of business, there has developed a new importance for the specialized firms doing business with the military in products like airframes, ships, and electronics, etc. Although the list includes many long-established large firms such as General Motors, General Electric, and Westinghouse, many other firms have developed a new economic importance in servicing the military in recent years. A few cases may be useful in illustrating this point. Table two demonstrates the growth and sharp fluctuations in sales volume by firms whose activity is chiefly in supplying the military. Chart two shows these data from 1940 through 1957 for several illustrative cases: an aircraft company, a shipbuilding firm, and an electronics manufacturer.

II

\section{DoIng Business with the Military}

Although at first glance it might seem that doing business with the military would be no different from commercial transactions with other customers, closer scrutiny will indicate some highly specialized conditions which make considerations of

\footnotetext{
1 The expenditure data cited here have not been adjusted for changes in the value of the dollar.
} 
CHART I

Gross National Product and National Security Expenditures (Unadjusted)* I940-57

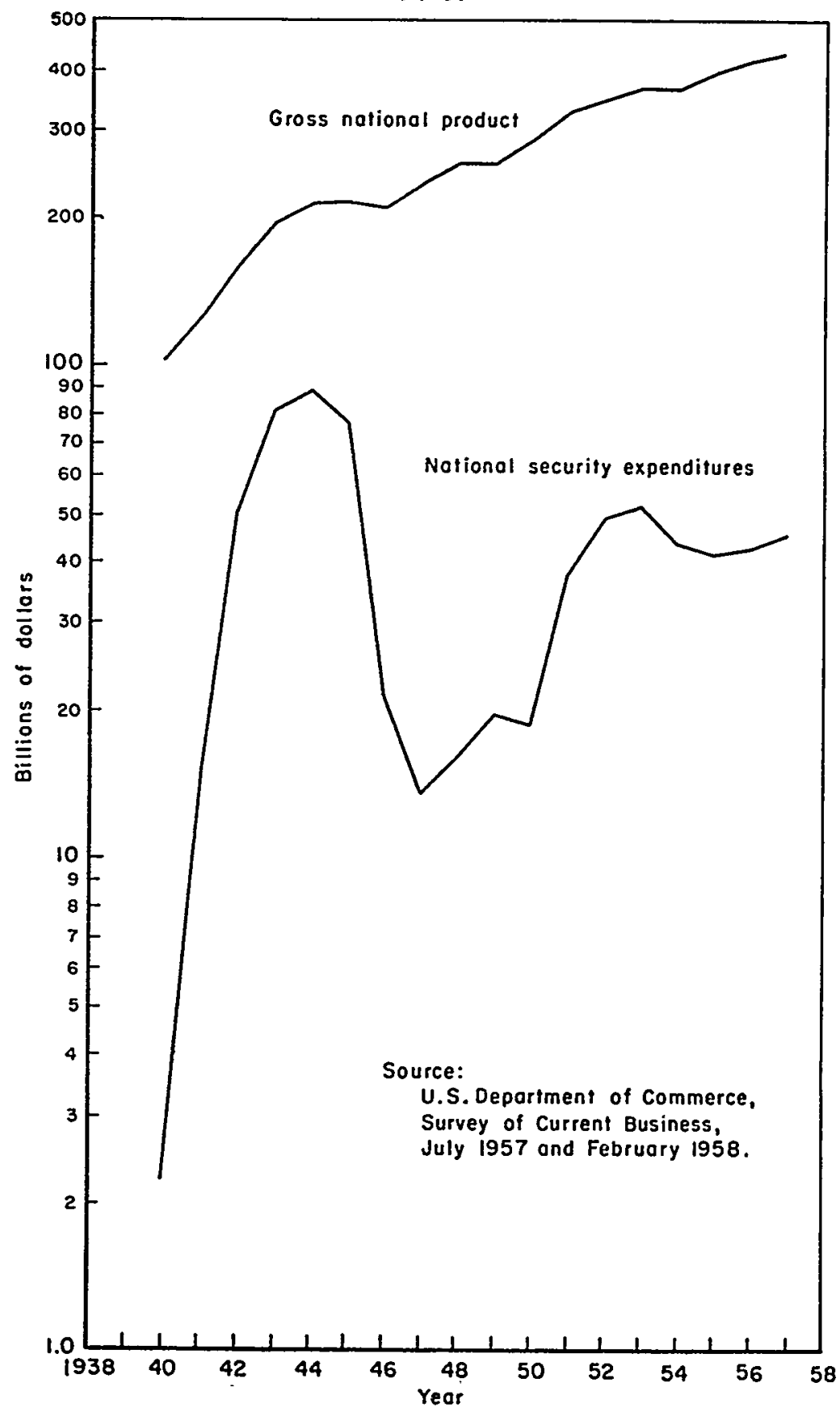

* In order to compare the rates of change, the data are presented on a semilogarithmic, or ratio, scale. 
TABLE II

Net Sales of 25 Companies with Large Proportions of Military Business, i950-57 (millions of dollars)

\begin{tabular}{|c|c|c|c|c|c|c|c|c|c|}
\hline \multirow[t]{2}{*}{ Company } & \multirow{2}{*}{$\begin{array}{c}\text { Total } \\
\text { Military } \\
\text { Contracts } \\
7-1-50- \\
12-31-55\end{array}$} & \multicolumn{8}{|c|}{ Net Sales } \\
\hline & & 1957 & 1956 & 1955 & 1954 & 1953 & 1952 & 1951 & 1950 \\
\hline Boeing Airplane Co... & $\$ 5957$ & $\$ 1596$ & $\$ 1006$ & $\$ 854$ & $\$ 1024$ & $\$ 912$ & $|\$ 732|$ & $\$ 337$ & 307 \\
\hline United Aircraft Corp. & 4465 & 1234 & 954 & 699 & 655 & 818 & 668 & 418 & 270 \\
\hline Douglas Aircraft Co........ & 3992 & 1091 & 1074 & 868 & 915 & 874 & 523 & 225 & 130 \\
\hline North American Aviation Inc.. & 3631 & 1244 & 914 & 817 & 646 & 635 & 315 & 178 & 143 \\
\hline General Dynamics Corp. *.... & 3517 & 1563 & 1083 & 731 & 764 & 693 & 618 & 482 & 372 \\
\hline Lockheed Aircraft Corp... & 3308 & 868 & 743 & 674 & 733 & 820 & 438 & 237 & 173 \\
\hline Curtiss-Wright Corp... & 2294 & 599 & 571 & 509 & 475 & 439 & 326 & 177 & 136 \\
\hline $\operatorname{Re}$ & 2270 & 269 & 346 & 547 & 324 & 412 & 412 & 130 & 58 \\
\hline Grumman Aircraft Engineering Corp & 1445 & 205 & 198 & 213 & 235 & 241 & 220 & 168 & 102 \\
\hline Sperry-Rand Corp. ${ }^{*} . \ldots \ldots \ldots \ldots \ldots$ & 1406 & 871 & 711 & 699 & 690 & 632 & 468 & 350 & 252 \\
\hline Aviation Corp.. & 1342 & 711 & 581 & 567 & 608 & 638 & 509 & 340 & 219 \\
\hline Ma & 1191 & 424 & $35 \overline{9}$ & 272 & 271 & 208 & 144 & 68 & 40 \\
\hline Northrop Aircraft Inc.. & 985 & 281 & 322 & 283 & 172 & 184 & 187 & 90 & 44 \\
\hline MoDonnell Aircraft Corp. & 866 & 335 & 186 & 155 & 123 & 134 & 82 & 67 & 39 \\
\hline Alco Products Inc...... & 769 & 161 & 170 & 121 & 187| & 441 & 340 & 235 & 139 \\
\hline ser Industries Corp. & 765 & 376 & 266 & 164 & 212 & 359 & 203 & 146 & 238 \\
\hline Faircbild Engine and Airplane $\mathrm{C}$ & 644 & 159 & 155 & 154 & 140 & 170 & 142 & 75 & 60 \\
\hline Corp.... & 503 & 202 & 216 & 204 & 186 & 146 & 129 & 82 & 36 \\
\hline es Powder Co.. & 478 & 255 & 244 & 234 & 195 & 197| & 188. & 222 & 166 \\
\hline Raytheon Manufacturing Co. & 434 & 240 & 176 & 182 & 177 & 179 & 111 & 90 & 60 \\
\hline Merrit-Chapman \& Sco & & 348 & 365 & 360 & 146 & 70 & 45 & 51 & 38 \\
\hline Collins Radio Co............ & 399 & 124 & 125 & 108 & 90 & 80 & 64 & 19 & 13 \\
\hline Newport News Shipbuilding and Dry & & & & & & & & & \\
\hline Dock Co................. & 393 & 178 & 118 & 123 & 150 & 157| & 147 & 89 & 52 \\
\hline Textror & 367 & 255 & 246 & 192 & 100 & 71 & 99 & 98 & 88 \\
\hline Vertol Aircraft Corp.. & 329 & 77 & 90 & 58 & 49 & 87 & 64 & 26 & 6 \\
\hline
\end{tabular}

*Totals for General Dynamics Corp. and Sperry-Rand Corp. include totals of major merged companies prior to merger.

EOURCES: Sales from AfOODY'B MIANUAL OF INVESTMENTS STANDARD CORPORATION RECORDS: miiltary contract totals from House Select Committee on Small Business, Final Report, H. R. Rep. No. 2970, 84th Cong., 2d Sess. 171-73 (1957).

success or failure quite different in the military market from those in normal trade. These involve, for example, the kinds of goods and specifications for them required by the services, the multiple decision processes involved in placing orders, historical attitudes towards the selection of vendors, and the violent fluctuations in total volume resulting from changes in the thinking of the Executive or the Congress regarding the level of expenditures that should be permitted in support of the armed forces.

Knowing what the military wants usually involves more than just contacting the buyers and looking at periodically published lists of contracts to be let. In order to be equal to or ahead of our potential enemies, the military demands continually press against the outer perimeter of both the current and the expected state-of-the-art made possible by science and technology. This means that most of the items of equipment which the armed services want can be supplied only by vendors who engage in extensive and expensive research and development programs.

The growth in importance and cost of research and development in recent years has meant that very few companies can themselves undertake the financial risks involved and, as a result, that most of the research and development is financed by 
CHART II

Net Sales of Three Military Contractors I940-57

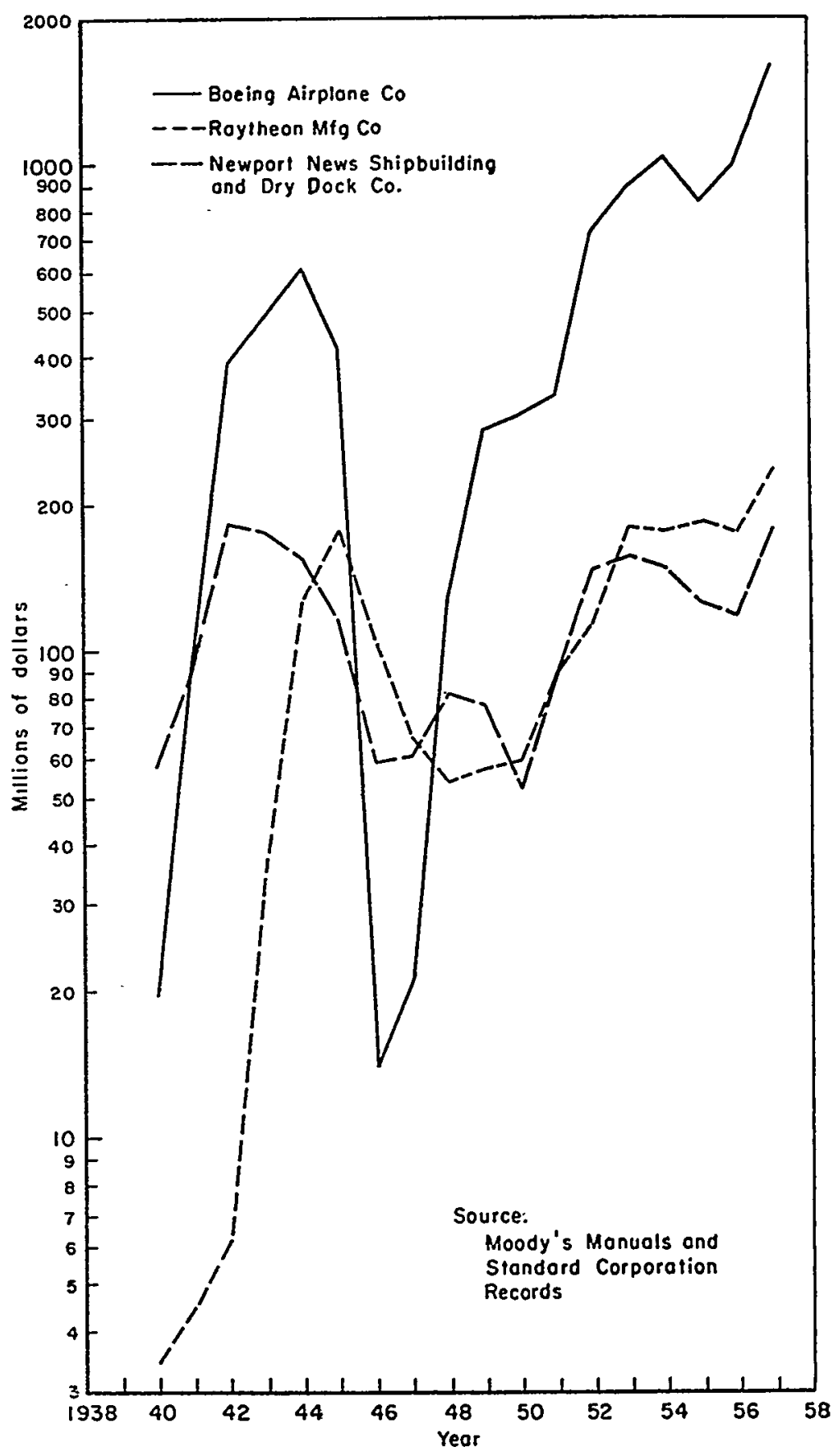


the Government. Even if there had not been a well-developed practice of placing procurement contracts with the firm which had done the research and development, technical and financial considerations might have forced such a relationship. In any event, there are relatively few suppliers-if any-who could undertake the delivery of finished weapons on the time schedules required if they had not actively participated in research and development for the selected item or one closely related to it.

In addition to design and knowledge related thereto, pushing the state-of-the-art involves specifications with respect to precision, new materials, and new fabricating processing which, again, seriously limit the ability of many companies to compete. Although there is a tendency to think of such machine marvels as color TV and automatic gear shifts as new, if we stop and think for a moment, the older ones among us will remember the twenty years or more between the first projection of these ideas and their introduction on the commercial maxket. The military cannot wait twenty years for the performance reliability and reasonable cost which are more or less normal in the commercial realm. Even though the businessman must think of the possibility of a competitor getting the jump on him, he does not have to think of the devastating and horrifying results of an error in decision which confront the Joint Chiefs of Staff when they are for the first time presented with the scientific possibility of creating a revolutionary new weapon. Although there are conditions under which this new capability can be achieved just a few steps beyond the existing state-of-the-art, in most cases, the projection means moving in a few years to a point to which normal commercial evolution would have brought us in twenty or more years.

Partly because of the very advanced ideas, but to a larger extent because of the nature of the legal and administrative procedures established by the Government and the military, selling to the armed services is not a simple and straightforward task. The military cannot know the quantity of an item it wants until it has reasonable assurance of its performance. Since the capability is based upon the realization of an as yet unestablished state-of-the-art, no one can know how good or worthwhile the proposal is until after an extensive test program. Under these circumstances, decisions to buy are a mixture of optimism, knowledge, and willingness to take numerous types of risks. As research and development becomes more and more expensive, cost considerations have become increasingly important. In any event, it is not easy to get a yes-or-no decision with respect to either the item or its quantity.

Requirements for the item will be changed continuously, as hopes are tempered by experience. Quantities will go up and down as the pragmatic estimate of the value of the final product changes. This process would make life commercially difficult even if it occurred at only one point. However, in the case of the military, this process takes place in at least four or five places, and often more.

For example, decisions affecting the eventual procurement of military equipment may be first drawn up and reviewed at one or more levels in the using command, bureau, or corps. Decisions thus made are referred first to the military staff of the 
appropriate headquarters in Washington and then to the Departmental Secretary's office. Those that survive are referred to the Department of Defense and, if approved there, to the Bureau of the Budget. It is apparent that this process will ordinarily require numerous interactions among the offices and agencies concerned, with resulting delays and extensive time lags, and that the final procurement decision will often bear little resemblance to the original proposal.

Against this multiplicity of military decision-making points, one can formulate his own estimate of the cost of representation and presentation which must be borne by the vendor in his search for military equipment business. When this is coupled with the other financial considerations involved and the necessity for having the mechanical and human capabilities to perform the job, it becomes apparent that substantial resources are required to do business with the armed services. Some measure of the magnitudes involved and particularly the changes which have occurred in recent years may be obtained by considering the changes in relative importance of research and development and procurement outlays for major weapons. Research and development costs for most types of World War II aircraft were ordinarily measured in hundreds of thousands or millions of dollars, with follow-on procurement outlays in tens or hundreds of millions. Research, development, and test on equipment such as the B-52 ran into millions, followed by procurement costs of billions. For the ballistic missile program, development costs (including test) are measured in billions and (depending on quantities of operational missiles procured) may even approach the ultimate procurement outlays.

Under present institutional arrangements, the real payoff to the vendor occurs only if the research and development effort can be converted into a procurement contract for the finished article. Three things are especially noteworthy: (I) the size of the research and development effort is, of itself, large; (2) the volume of procurement is so large as to require very substantial resources; and (3) the growth in research and development, together with the decline in the relative importance of procurement, makes the financial ability to enter into research and development a matter of prime importance.

The increase in the relative importance of the cost of research and development is impressive and overwhelming from a commercial point of view. Although unclassified data on research and development costs for individual weapons currently under development are not available, the Patman Committee published a list ${ }^{2}$ of the companies and institutions receiving the largest amounts of military research and development contracts in fiscal years $1954-56$. Table three shows these data for major companies whose business is primarily military, together with the companies' net worth in 1956 . The magnitude of the research and development figures indicates that in many cases, the effort would be beyond the capability of a small firm and

\footnotetext{
${ }^{3}$ House Select Committee on Small Business, Final Report, H.R. Rep. No. 2970, 84th Cong., 2d Sess. I7т-73 (I957).
} 
TABLE III

Twenty Companies with Large Proportions of Military Business: Military Research and Development Contracts and Net Worth (millions of dollars)

\begin{tabular}{|c|c|c|}
\hline Company & $\begin{array}{c}\text { Military Research and Devel- } \\
\text { opment Contracts Fiscal } \\
\text { Years 1954-56 }\end{array}$ & Net Worth 1956 \\
\hline 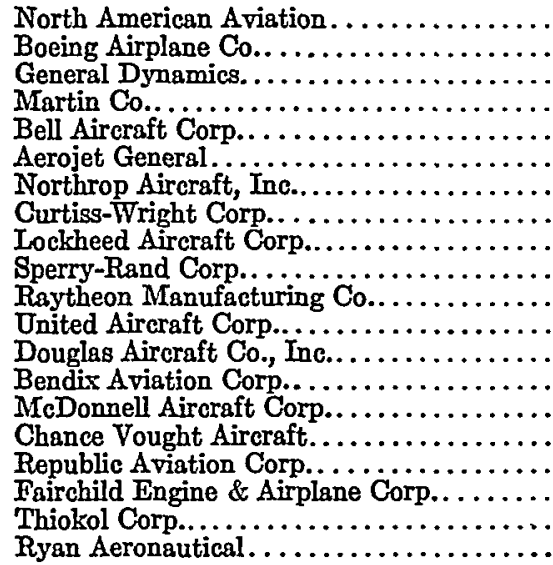 & $\begin{array}{r}\$ 421 \\
212 \\
169 \\
136 \\
134 \\
115 \\
105 \\
98 \\
84 \\
83 \\
71 \\
67 \\
39 \\
34 \\
32 \\
32 \\
30 \\
25 \\
21 \\
17\end{array}$ & $\begin{array}{r}\$ 153 \\
149 \\
143 \\
64 \\
39 \\
16 \\
28 \\
183 \\
107 \\
254 \\
43 \\
219 \\
153 \\
177 \\
28 \\
29 \\
46 \\
37 \\
6 \\
11\end{array}$ \\
\hline
\end{tabular}

* Parent corporations and subsidiaries not consolidated in all cases.

EOUnces: Research and Development contract totals from House Select Committee on Small Business, Final Report, H. R. Rep. No. 2070, 84thy Cong., 2d Sess. 87 (1957); net worth from MOODY's MANUALS OF LNVEsTsreNTs.

that in others, if they were, indeed, undertaken and proved unsuccessful, the result would be financial catastrophe.

There may be some who will experience a feeling of dismay toward these high costs of research and development, especially when they may tend to drive smaller concerns out of the market as prime contractors. It should be recognized, however, that unlike production, where timing and volume can be calculated fairly well in advance, research and development is very often an attempt to exploit a chain of reasoning which rests in part on proved scientific principles, in part on plausible hypotheses, and in part on intuition or informed opinion on the part of specialists. Added to this usually are requirements for retention of high strength of materials under increasingly high temperature, finer and finer tolerances of fit, and the highest attainable level of reliability. The combination of all these means, in economic terms, the need to build and staff highly specialized laboratories and to support them for periods of unpredictable length, while a high-priced scientific and engineering staff, supported by skilled craftsmen, run down one promising lead after another. There is very little that is predictable in this process; there is no way of guaranteeing results.

In addition to the types of problems involved in selling the military which have been enumerated above, there is another and perhaps more potent condition arising from the nature of our annual budget-making process. In times of crisis, as in 
World War II and Korea, there is a tendency for Congress and the Executive to make huge sums of money available to the military. When the crisis is over, there is a very real desire to cut taxes and move towards balancing the budget and, therefore, to cut back on military expenditures. The change in weapons procurement from I940-45, as compared to I945-50, is striking. In terms of what we can expect in the cold war, the changes that have occurred since $195^{\circ}$ are probably even more significant. (See chart one.)

From a commercial point of view, the important thing is the large volume of business and numbers of vendors that are brought in during the crisis expansion. When the cutback takes place, this naturally hits not only the established vendors, but more particularly the new vendors who have just gotten started. This means then that the usual changes in executive and congressional policy with respect to expenditures for military weapons produce a feast-or-famine condition which makes commercial survival extremely difficult. The sum of all these conditions means that it is not easy to do business with the military; this is reflected in the attitude of the bankers and the investment fraternity towards financing military vendors. Perhaps equally noteworthy is the oft-repeated attitude of companies who can employ their resources for nonmilitary purposes. After one or two sessions of doing business with the military, some will say, "never again."

\section{III}

\section{WeAPon-System Concept}

Within the last few years, beginning notably with the Air Force procurement of the $\mathrm{B}_{-5} 8$ bomber in 1954 , the so-called weapon-system concept has become important. The change here is particularly noteworthy, since it means placing the total system responsibility (excluding only power plant in the case of the $\mathrm{B}-5^{8}$ ) in the hands of a single source. Prior to this time, the major components-such as airframe, bombardment-navigation system, or communications equipment-were bought from separate sources and were Government-furnished equipment to be incorporated in the final product by the airframe producer. Under the weapon-system concept, these items become contractor-furnished equipment, and a single vendor assumes complete responsibility for the total system. In varying degree, this concept has now been applied to other major Air Force procurements such as the B-70, the F-ro8, and the Atlas, Titan, and Thor.

There are two major reasons for this new way of buying weapons.

First, the mating or system-integration problem-that is, the combining of the various components into the final assembly-becomes more and more severe as weapon-system complexity increases. Obviously, when separate producers are developing each of the component items, in the course of the years that elapse from initial projection to delivery, the search for high performance may lead to departures from specification and configuration that will make mating well-nigh impossible. This becomes particularly important in airborne vehicles, where the search for weight 
and space savings is extremely important and the configuration of the final structure has a marked effect on total performance.

Second, there are operational problems which cannot be taken fully into account in evaluating the separate articles. It is only as a total system that the equipment is operational and all the problems involved in both its airborne and ground handling activities become apparent. Let us develop these two points.

As the military moved toward the more and more advanced equipment, they have repeatedly encountered situations in which one component meets or exceeds the original specifications and another falls behind by a wide margin. Under these circumstances, the final system-integration usually produces an article which suffers from the lowest level of component achievement. To deal with this problem and to ensure greater compatibility of the components, the weapon-system concept has developed with the hope of insuring capability of the final assembly. There has been considerable discussion and negative criticism of this approach because it reduces the number of prime contractors and places a great deal of economic power in the hand of the successful bidder. ${ }^{3}$

Although this might be commercially undesirable, none the less the objectives and purposes of the weapon-system concept are desirable. If we can, in fact, achieve a more uniform state of progress, particularly in the sense that we can boost the laggards, and since the weapon-system concept seems to facilitate the joining program, there is much to be said in favor of this way of doing business. In a race for scientific and technical supremacy, it is important not only that each of the components be of advanced design, but more important that the final product be capable of the utilization of their separate achievements.

As indicated earlier, modern research and development has become very big business. In fact, as indicated in table three, the expenditures involved frequently far exceed the net worth of the designer. In addition, the skills involved usually go beyond the capabilities of a single company. As a consequence, there is now a tendency for various companies to form groups in which they bid on the weaponsystem proposal. Under the newly developing scheme, each company takes its specialized part and makes a contribution both technically and resource-wise to the combine, although the end product is viewed essentially as a single weapon-system contract. The economic effect under the new condition is substantially the same as that of the previous method of weapon-system procurement management.

IV

Economic Role of Small Business

According to data recently released by the Department of Defense, ${ }^{4}$ about twenty per cent of the net value of all military prime contracts during fiscal years $195 \mathrm{I}-57$

\footnotetext{
${ }^{3}$ For a discussion of the weapon-system concept, see NeIL E. HarLan, Management Control in AIRFRAME SUBCONTRACTING 25I-53 (1956).

'Ass't Secretary of Defense (Supply and Logistics), U.S. Dep't of Defense, Military Prime Contracts Wite Small Business and Other Competitors, Fiscal Year ig57 Sumimary (i957). In
} 
have been awarded to small business firms. As indicated in table four, the proportion of military business going to small business differs markedly among the three military departments, amounting in fiscal year 1957 to about forty per cent for the Army, twenty per cent for the Navy, and eight per cent for the Air Force. This reflects the predominance of aircraft, missiles, ships, and other heavy equipment in Air Force and Navy procurement and, in Army procurement, the greater proportion of items not requiring large specialized manufacturing facilities.

The differences by type of commodity procured are shown more clearly in table five. As would be expected, the heavy concentration of awards to small business has been in civilian-type production-construction, textiles, and clothing, subsistence, and so forth. For major items of military equipment, small business participation in prime contracts (in fiscal year 1957) ranged from 13.5 per cent for ships to only r.9 per cent for guided missiles and 0.4 per cent for airframes and related assemblies.

These percentages, it should be noted, reflect only prime contracts awarded by the military. If summary data were available showing small business' participation by way of subcontracts or through the sale of parts, components, materials, services, etc. to the prime contractors, the percentages would be very substantially higher for most types of major equipment. ${ }^{5}$

To the extent that small business wishes to expand its role as a prime contractor, it must be able to meet the economic requirements for doing business with the military which have been indicated in the preceding sections. This means being able to undertake the types of research and development essential to make equipment proposals to the armed services or having a sufficiently advanced manufacturing capability to meet the specifications for new materials, products, and processes if the design which the military requires has been developed by another firm.

For some types of products, particularly simple items of electronics and the like, small business may be able to compete. On the other hand, for most of the articlesparticularly end items and major components-the resource requirement is so substantial that it is unlikely that a firm which meets the small business definition can be in a position to compete with large firms. In doing business with the military, the normal commercial difficulties are compounded by the multiple decision-making points which must give the go-ahead before the Government can proceed and by the difficulties of decision implicit in the projection of the state-of-the-art which characterizes most future weapons. This means continued representation and presentation on the part of the vendor, with the high costs and risks that go with it. Again, substantial resources are usually required.

this compilation, "small business firms" are defined as "concerns which are not dominant in their ficlds of operation and which, together with their affiliates employ fewer than 500 persons, and those with 500 or more employees which have been certified by the Small Business Administration as small business firms."

"For a discussion of subcontracting in the airframe industry, see John S. DAx, Subcontractino Policy.in the AIRframe Industry esp. 321-27 (1956); Hardan, op. cit. supra note 3. For a statement of the Air Force policy, see Hearings Before the Senate Subcommittee of the Committee on Appropriations on H.R. 12738, 85th Cong., 2d Sess. 897, 907 et seq. (1958). 
The historic practice of the military departments of giving a production contract to a firm that has done the research and development means that in terms of modern weapons, a potential supplier must be able to finance a substantial research and development effort. Although the Government eventually pays for most of these outlays, the problems of financing them are none the less real and are only possible for firms of substantial size. Again, the production of the finished articles reaches a dollar volume which is beyond the financing capacities of most small firms.

Even when the small firm, either by its own efforts or by entering into a combination with others, is able to meet the difficulties outlined above, it still runs an extraordinary risk resulting from our start-and-stop, stop-and-start policy on military expenditures. If there were a continuity either in the total volume or in dollars devoted to specific end products, it is possible that small business could work its way into military procurement just as it has into the supplying of commercial articles. However, when the Executive and the Congress change their minds so frequently, and with the volume impact that has taken place in recent years, the risks become almost unacceptable for the small firm.

Although the weapon-system concept has been singled out recently as a special ogre for the small businessman, it does not appear that this introduces any greater difficulties than are already presented in the existing system of military procurement. Even if it did, the primary objective of the weapon-system concept-that is, the earlier and more complete fulfillment of goals-would indicate that national security should be given first consideration in evaluating its impact on small business.

TABLE IV

Small Business Percentage of Military Procurement by Department Fiscal Years $195 \mathrm{I}-57$

\begin{tabular}{|c|c|c|c|c|c|}
\hline & Fiscal Year & $\begin{array}{c}\text { Total } \\
\text { Military }\end{array}$ & Army & Navy* & Air Force \\
\hline Total & 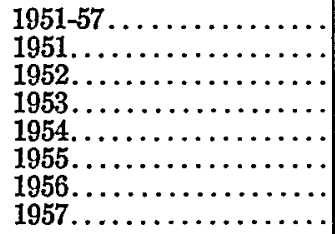 & $\begin{array}{l}19.3 \% \\
20.9 \\
17.0 \\
16.6 \\
25.3 \\
21.5 \\
19.6 \\
19.6\end{array}$ & $\begin{array}{l}32.3 \% \\
29.8 \\
21.2 \\
36.5 \\
76.5 \\
42.6 \\
43.7 \\
40.6\end{array}$ & $\begin{array}{l}20.0 \% \\
16.3 \\
22.7 \\
19.4 \\
21.1 \\
18.8 \\
19.7 \\
20.8\end{array}$ & $\begin{array}{r}7.5 \% \\
9.9 \\
5.7 \\
4.5 \\
10.3 \\
9.1 \\
8.3 \\
8.2\end{array}$ \\
\hline
\end{tabular}

*Includes procurement actions of the Military Petroleum Supply Agency and its predecessor the Armed Services Petroleum Purchasing Agency.

Source: Ass't Sechetary of Defenge (Supply and Lootstics), U. S. Dept. of Defense, Mitutary Prame Contracta wite Sualu Bubiness and Other Contractons, Fiscal Year 1957 Suamaky 10 (1957).

\section{Conclusion}

The nature of modern weapons and their importance to the national security of our nation makes the economics of weapons development and procurement a primary national issue. As we push upon the scientific, technical, and fabricating states-of-thearts, it becomes both more difficult and more expensive to meet the requirements 
TABLE V

Small Business Percentage of Military Procurement Actions of \$ro,0oo or More with Business Firms by Procurement Program

Fiscal Years I955-I957

\begin{tabular}{|c|c|c|c|c|c|}
\hline Rank & Program Title & $\begin{array}{c}\text { Average for } \\
1955-57\end{array}$ & 1955 & 1956 & 1957 \\
\hline $\begin{array}{l}1 \\
2 \\
3 \\
4 \\
5\end{array}$ & 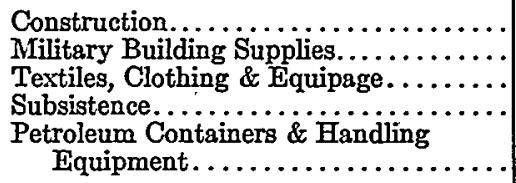 & $\begin{array}{l}66.8 \% \\
65.3 \\
60.2 \\
52.9 \\
51.6\end{array}$ & $\begin{array}{l}65.5 \% \\
74.0 \\
50.7 \\
52.7 \\
84.5\end{array}$ & $\begin{array}{l}71.8 \% \\
68.2 \\
67.2 \\
56.0 \\
85.9\end{array}$ & $\begin{array}{l}63.6 \% \\
54.3 \\
61.3 \\
50.3 \\
26.2\end{array}$ \\
\hline $\begin{array}{r}6 \\
7 \\
8 \\
9 \\
10\end{array}$ & 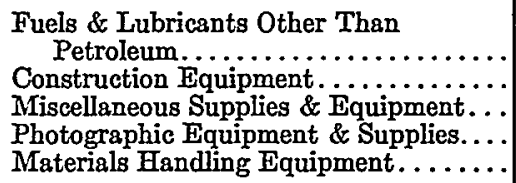 & $\begin{array}{l}50.0 \\
46.4 \\
44.1 \\
36.0 \\
35.4\end{array}$ & $\begin{array}{l}59.7 \\
54.9 \\
43.6 \\
35.8 \\
33.1\end{array}$ & $\begin{array}{l}56.4 \\
42.5 \\
41.1 \\
40.7 \\
45.5\end{array}$ & $\begin{array}{l}42.0 \\
18.7 \\
48.0 \\
31.2 \\
31.2\end{array}$ \\
\hline $\begin{array}{l}11 \\
12 \\
13 \\
14 \\
15\end{array}$ & 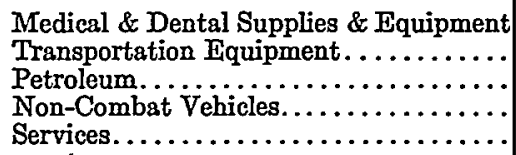 & $\begin{array}{l}32.8 \\
26.2 \\
20.2 \\
19.9 \\
16.5\end{array}$ & $\begin{array}{l}38.1 \\
25.7 \\
12.4 \\
18.0 \\
36.5\end{array}$ & $\begin{array}{l}29.8 \\
31.1 \\
20.7 \\
25.1 \\
12.3\end{array}$ & $\begin{array}{r}31.2 \\
13.4 \\
22.8 \\
18.1 \\
9.7\end{array}$ \\
\hline $\begin{array}{l}16 \\
17 \\
18 \\
19 \\
20\end{array}$ & 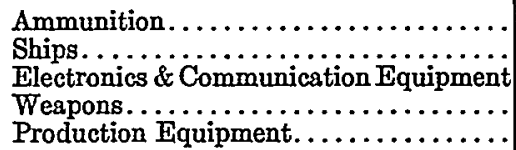 & $\begin{array}{r}15.6 \\
13.7 \\
10.3 \\
9.9 \\
8.9\end{array}$ & $\begin{array}{r}15.0 \\
15.7 \\
11.8 \\
12.1 \\
9.2\end{array}$ & $\begin{array}{r}18.2 \\
12.5 \\
10.2 \\
11.3 \\
5.3\end{array}$ & $\begin{array}{r}14.4 \\
13.5 \\
0.4 \\
6.1 \\
24.1\end{array}$ \\
\hline $\begin{array}{l}21 \\
22 \\
23 \\
24 \\
25\end{array}$ & 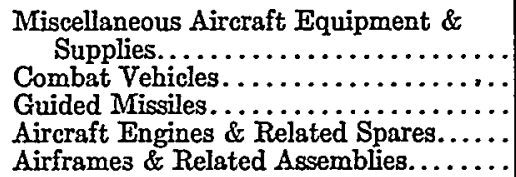 & $\begin{array}{l}7.3 \\
4.4 \\
2.2 \\
1.0 \\
0.4\end{array}$ & $\begin{array}{l}7.9 \\
4.5 \\
2.9 \\
0.7 \\
0.4\end{array}$ & $\begin{array}{l}6.7 \\
4.5 \\
2.1 \\
0.8 \\
0.2\end{array}$ & $\begin{array}{l}7.4 \\
4.2 \\
1.9 \\
1.9 \\
0.4\end{array}$ \\
\hline
\end{tabular}

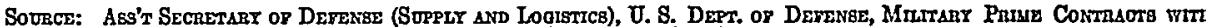

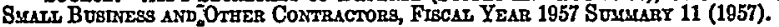

for defending the country. The cost of research and development has reached major proportions. The investment required to do business with the Government is very large. Having the ability to supply the procurement demands for modern weapons thus involves very substantial resources on the part of the vendor.

Although military procurement is a major economic force in this country today, it does not seem possible quickly or easily to design the nature of this process away from large-scale enterprise. Even if some of the resource-demanding features such as representation and presentation were rationalized and made cheaper, two other conditions would make it difficult for small enterprise to compete. One of these is in the very nature of the process-that is, the tremendous resource requirement involved either in research and development or in production. The other is a political matter which neither the Executive nor the Congress has given any indication of an ability or willingness to solve-the stop-and-go or feast-or-famine programming of 
funds for national security. It is not unlikely that from the small business point of view, this last is the most critical consideration. If the federal government were to lay on a long-range program for procurement of military end products, then small business might be able to find a way to get into the business. That means projections beyond the two and three years that we now make. Perhaps most important of all, it would require that we recognize the continuity of the preparedness effort and establish a minimum procurement level for something like the next ten years. If that were done, there would be a stability in the weapons business that would facilitate the appropriate commercial planning, and in such a situation, small business should be able to get its share. 